\title{
The Influence of Summer Climate on Avian Community Composition in the Eastern Boreal Forest of Canada
}

\section{Influence du climat estival sur la composition de la communauté aviaire dans la forêt boréale de l'Est du Canada}

\author{
Jean-Luc DesGranges $^{1}$ and Mélanie-Louise LeBlanc ${ }^{2}$
}

\begin{abstract}
Understanding the relative influence of environmental variables, especially climate, in driving variation in species diversity is becoming increasingly important for the conservation of biodiversity. The objective of this study was to determine to what extent climate can explain the structure and diversity of forest bird communities by sampling bird abundance in homogenous mature spruce stands in the boreal forest of the Québec-Labrador peninsula using variance partitioning techniques. We also quantified the relationship among two climatic gradients, summer temperature and precipitation, and bird species richness, migratory strategy, and spring arrival phenology. For the bird community, climate factors appear to be most important in explaining species distribution and abundance because nearly $15 \%$ of the variation in the distribution of the 44 breeding birds selected for the analysis can be explained by climate. The vegetation variables we selected were responsible for a much smaller amount of the explained variation (4\%). Breeding season temperature seems to be more important than precipitation in driving variation in bird species diversity at the scale of our analysis. Partial correlation analysis indicated that bird species richness distribution was determined by the temperature gradient, because the number of species increased with increasing breeding season temperature. Similar results were observed between breeding season temperature and the number of residents, shortdistance and long-distance migrants, and early and late spring migrants. Our results suggest that the northern and southern range boundaries of species are not equally sensitive to the temperature gradient across the region.
\end{abstract}

RÉSUMÉ. La compréhension du rôle de l'influence relative des variables environnementales - particulièrement le climat -, sur la variation de la diversité des espèces revêt une importance grandissante pour la conservation de la biodiversité. L'objectif de cette étude était de déterminer à quel point le climat peut expliquer la structure et la diversité des communautés d'oiseaux forestiers, à partir d'un échantillonnage de l'abondance des oiseaux dans des peuplements d'épinettes matures et homogènes de la péninsule Québec-Labrador au moyen de techniques de partitionnement de la variance. Nous avons également mesuré la relation de deux gradients climatiques - la température estivale et les précipitations - en fonction de la richesse en espèces, de la stratégie migratoire et de la phénologie de l'arrivée printanière des oiseaux. Pour ce qui est de la communauté aviaire, les facteurs climatiques semblent le mieux expliquer la répartition et l'abondance des oiseaux, parce que près de $15 \%$ de la variation de la répartition de 44 espèces nicheuses sélectionnées pour l'analyse est expliquée par le climat. En revanche, les variables de végétation que nous avons choisies n'ont expliqué que $4 \%$ de la variation. Les températures durant la saison de reproduction semblent entrainer davantage de variation que les précipitations sur la diversité des espèces à l'échelle de notre analyse. L'analyse des corrélations partielles a indiqué que la distribution de la richesse en espèces était déterminée par le gradient de température, parce que le nombre d'espèces a augmenté avec la hausse de la température durant la saison de reproduction. Des résultats similaires ont été observés entre la température durant la saison de reproduction et le nombre d'espèces résidentes, le nombre de migrateurs de courte et de longue distance, et le nombre de migrateurs printaniers hâtifs et tardifs. Nos résultats laissent croire que les limites nord et sud de la répartition des espèces n'ont pas la même sensibilité au gradient de température dans l'ensemble de la région.

Key Words: avian community, boreal forest, climate, multivariate analysis

${ }^{1}$ Research Scientist, Wildlife Research Division, Environment Canada,

${ }^{2}$ Contractor, Environment Canada

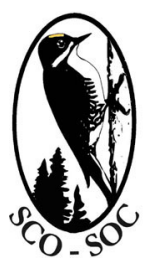

Sponsored by the Society of Canadian Ornithologists and Bird Studies Canada

Parrainée par la Société des ornithologistes du Canada et Études d'oiseaux Canada

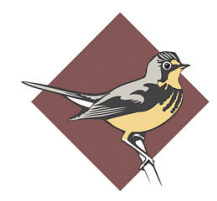

BIRD STUDIES CANADA 


\section{INTRODUCTION}

Global climate change is expected to lead to profound changes in the composition of most biota, and studies demonstrate that there have already been biotic responses to the relatively small climate changes that occurred during the last hundred years in North America (Walther et al. 2002, Root et al. 2003). Understanding the relative influence of environmental variables, especially climate, in driving variation in species diversity is thus becoming increasingly important for the conservation of biodiversity (Tellería et al. 1992, Walther et al. 2002, Root et al. 2003). However, the relative importance of how climate factors can shape biogeographical patterns of composition and avian diversity is less documented mainly because much of the research on bird communities has been focused on fragmentation of forest habitat, particularly where there has been permanent forest loss due to agricultural and urban expansion, and harvesting (Norton and Hannon 1997, Schmiegelow and Mönkkönen 2002, Drapeau et al. 2003).

Many migratory and resident bird species inhabiting mature black spruce (Picea mariana) stands in the boreal forest of Canada's Québec-Labrador peninsula are accustomed to a wide range of conditions in their seasonal environment (Mengel 1964, Møller et al. 2010). This region has the advantage of encompassing a strong climatic gradient across the landscape from the maritime climate of the Labrador coast to the relatively more continental and drier climate of the James Bay coast (Litynski 1984). Several recent studies have highlighted that climate seems to be an important determinant of geographic range for many birds (Root 1988, Thomas and Lennon 1999, Wormworth and Sekercioglu 2011). Virkkala and Rajasärkkä (2011) found that population changes in boreal birds in Finland's protected areas were best explained by an interaction between distribution pattern (southern species vs. northern species) and migratory strategy. A species-specific climate envelope may be the reason why different groups have different patterns of distribution along geographical gradients. For example, long distance migrant birds might be expected to be mostly found in the warmest portions of the boreal forest because of their food requirements. Long distance migrants are mostly insectivorous when breeding, and peak in abundance of herbivorous insects is closely correlated to local climate conditions (Both 2010). This situation may not, however, be the case for all long distance migrants. A study on the potential sensitivity of breeding birds in southern Québec found that the Bay-breasted Warbler (Setophaga castanea), Tennessee Warbler (Oreothlypis peregrina), Lincoln's Sparrow (Melospiza lincolnii), and Swainson's Thrush (Catharus ustulatus), all long distance migrants, are associated with a cool and wet summer climate and have been identified as potentially sensitive to future climate change (DesGranges and Morneau 2010). Even though these species are present across the region, they may be more strongly associated with the mature stands in the northeast of the
Québec-Labrador boreal forest. Although DesGranges and Morneau (2010) observed that resident species do not seem to be responsive to climate variables, another study suggests their distribution during the breeding period may be influenced by spring temperature (Lemoine and Böhning-Gaese 2003).

Among the numerous ecological factors that determine the spatial variation of bird species richness, climate seems to be important at a broad geographical scale (Tellería and Santos 1994). Birds are likely to react directly to climate change events such as repeated periods of rain, frost, and heat, and indirectly to changes in the environment that influence features such as food availability, habitat structure, and relationships among organisms. Because of the milder climate expected throughout most of the province of Québec in coming decades, certain bird species' ranges are predicted to expand northward (Berteaux et al. 2010). If temperature is one of the main drivers of bird species richness, we could expect more bird species in the southern portion of the boreal forest.

In this study, we examined forest bird community structure in the eastern boreal forest by quantifying the explanatory role of environmental and spatial variables. Specifically, we investigated to what extent climate can explain the structure and diversity of these forest bird communities by sampling bird abundance in homogenous mature spruce stands across the study region and by using variance partitioning techniques. To further understand the relationship between climate and avian communities, we wanted to qualify the relationship between climate factors and species richness, migratory strategy, i.e., long-distance migrants, short-distance migrants, and residents, and spring arrival phenology, i.e., early and late spring arrival. Our results provide a novel analytical approach toward understanding the effects of climate on bird species composition and diversity.

\section{METHODS}

\section{Study area}

This study took place in the eastern boreal forest region of Canada (49 $26^{\prime} \mathrm{N}$ to $53^{\circ} 11^{\prime} \mathrm{N}, 78^{\circ} 35^{\prime} \mathrm{W}$ to $63^{\circ} 19^{\prime} \mathrm{W}$; Fig. 1 ). To ensure enough contrast within the climate variables, the study area was spread out along two major altitudinal gradients that run south to north from the Saint-Lawrence North Shore to central Nouveau-Québec $(\sim 500 \mathrm{~km})$, and west to east from the James Bay coast to the Labrador coast $(\sim 1000 \mathrm{~km})$. The landform in the western portion of the boreal forest in Québec is composed of old marine terraces along the James Bay coast followed by gently rolling hills inland all along the La Grande hydrological complex (Robitaille and Saucier 1998). This region is characterized by a relatively dry climate; annual rainfall varies from $600 \mathrm{~mm}$ to $1000 \mathrm{~mm}$ and the annual mean temperature ranges from $-2.5^{\circ}-0.0^{\circ} \mathrm{C}$ (Litynski 1984). The landscape in the eastern portion of the boreal forest in Québec and Labrador is characterized by old marine terraces along the 
Saint-Lawrence North Shore and Lake Melville in Southern Labrador, the Manicouagan Reservoir ( $400 \mathrm{~m})$, gently rolling hills, and mountainous ranges with a maximum altitude of $1100 \mathrm{~m}$ (Groulx Mountains, Otish Mountains, Stevenson Mountains, and Mealy Mountains; Robitaille and Saucier 1998). This region is characterized by a maritime climate. The annual mean temperature ranges from $-2.5^{\circ}-0.0^{\circ} \mathrm{C}$, and annual rainfall varies from $1000 \mathrm{~mm}$ to $1400 \mathrm{~mm}$ (Litynski 1984).

Fig. 1. Location of the study area in the eastern Canadian Boreal Shield, a forest region dominated by black spruce (Picea mariana).

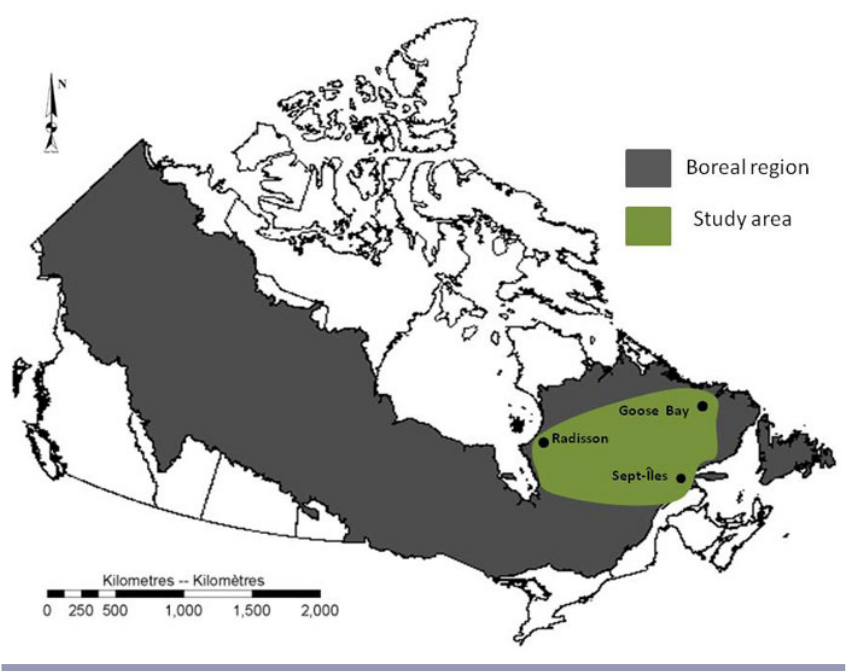

\section{Breeding bird data set}

We conducted bird surveys ("complete counts") during the active breeding season ( 6 June to 13 July in 2007, 2008, and 2009) in 337 homogenous mature black spruce stands of known surface area. To ensure a complete coverage of the boreal forest of Québec and Labrador, selected stands were easily accessible and randomly spaced along the forest roads that exist in that remote section of the province. To make the effects of climate on forest bird distribution and abundance emerge, only mature black spruce stands embedded in a similar landscape matrix were sampled. This unique approach also allowed us to control for the effects of landscape and forest composition on bird communities. Selected stands were visited once early in the morning, between 5:00 am and 8:30 am (Eastern Standard Time), on calm days without strong winds $(<=25 \mathrm{~km} / \mathrm{hr})$ or continuous rain. To maximize the probability of detecting most bird species, each section of the sampled region was surveyed during the early (early June), middle (mid June), and late (late June/early July) parts of the breeding season. Observers recorded all birds seen and/or heard while they moved throughout the stand to improve detection of cryptic species and species that utilize large territories, e.g., grouse. The time (mean $=48$ minutes) spent in stands was proportional to stand surface area (mean $=8.1$ ha). Because time and surface area varied between sampled stands, we grouped stands located less than $5 \mathrm{~km}$ apart and that shared the same ecoregion into 74 clusters. Bird abundance corresponds to the total abundance of birds divided by the sum of the surface area of each cluster (called sites hereafter). Simple correlation analysis (d.f. $=74$ ) showed that the sampling effort did not vary across the study region after grouping (latitude/surface area, $r=0.001, p=0.99$; latitude/ time, $\mathrm{r}=0.076, \mathrm{p}=0.52 ;$ longitude/surface area $\mathrm{r}=-0.022, \mathrm{p}$ $=0.86 ;$ longitude/time, $\mathrm{r}=-0.057, \mathrm{p}=0.63$ ).

\section{Environmental variables}

We quantified stand structure and forest composition in each stand. The percentage of trees (above $2 \mathrm{~m}$ in height with diameter at breast height $[\mathrm{DBH}]>9 \mathrm{~cm}$ ), sapling cover (DBH $<9 \mathrm{~cm}$ ), and regeneration were recorded for the most abundant woody species in each stand. We also recorded the percentage of canopy cover. From these measurements, we calculated seven habitat parameters that consisted of percent cover for black spruce (\%), balsam fir (Abies balsamea; \%), white spruce (Picea glauca; \%), deciduous trees (\%), lateral cover $(\%)$, conifer regeneration $(\%)$, and total canopy cover $(\%$; Table 1). Habitat variables were expressed as a mean for each site $(n=74)$ and were arcsine-transformed before analyses.

Climate variables were estimated from the ANUSPLIN model, which is a bioclimatic prediction system that uses surrogate terms (bioclimatic parameters) derived from mean monthly climate estimates to approximate energy and water balances at a given location (McKenney et al. 2007). A key contribution of this model has been the systematic incorporation of elevation as a predictor, particularly for temperature and precipitation.

Climate factors such as temperature and precipitation correlate with range boundaries of birds (Newton 2003, DesGranges and Morneau 2010). To ensure a full coverage of different climatic conditions that can occur during the breeding season (late spring to early summer), we selected six temperature and precipitation related climatic variables, i.e., monthly maximum temperature and precipitation for the months of May, June, and July. A preliminary principal component analysis (PCA) on the entire data set (68 variables), however, showed a high correlation between seasonal climatic variables. To reduce redundancy among variables, we used mean trimonthly values for temperature and precipitation. Hence, only two climatic related variables, breeding season mean temperature (BST) and breeding season mean precipitation (BSP), were used in the analyses (Table 1). We also selected two measures that provide an estimate of vegetation growth, start of growing season (SGS) and number of growing degree days (GDD; Table 1). The Julian day number for the start of the growing season corresponded to the Julian day number of the last day of five consecutive days when the mean daily temperature was above $5^{\circ} \mathrm{C}$ (no sooner than 1 March and no 
Table 1. Definition and mean (SE) of environmental variables included in the analysis from stands sampled within the boreal forest of Québec, Canada.

\begin{tabular}{llc}
\hline \hline Variables & Description & Mean $( \pm$ SE) \\
\hline Climate & Description from McKenney et al. 2007 & Breeding season mean temperature \\
BST & mean of 30 year $(1971-2000)$ average May, June, and July mean maximum temperature $\left({ }^{\circ} \mathrm{C}\right)$ & $15.48(0.17)$ \\
& Breeding season mean precipitation & \\
BSP & mean of 30 year $(1971-2000)$ average May, June, and July precipitation $(\mathrm{mm})$ & $775.38(19.05)$ \\
& Number of growing degree days & $140.84(0.80)$ \\
GDD & The start of growing season & $37.60(1.95)$ \\
SGS & & $6.63(1.16)$ \\
Habitat & Percentage of black spruce $($ Picea mariana $)$ & $2.08(0.92)$ \\
BS & Percentage of balsam fir (Abies balsamea $)$ & $1.13(0.40)$ \\
BF & Percentage of white spruce $($ Picea glauca $)$ & $36.11(1.83)$ \\
WS & Percentage of deciduous trees & $51.0(0.03)$ \\
D & Percentage of lateral cover & $78.0(0.02)$ \\
LC & Percentage of conifer regeneration & \\
CR & Percentage of canopy closure &
\end{tabular}

later than 31 July; McKenney et al. 2007). GDD, which is estimated as the cumulative sum of the degree-days above $5^{\circ}$ $\mathrm{C}$ for the growing season, has been used in horticulture to predict flowering dates and also in agriculture to predict yield, and has been used as a proxy for vegetation growth (Moyes et al. 2011). The climate variables were $\ln$-transformed (ln $[\mathrm{x}+1])$.

\section{Statistical analysis: species composition}

Multivariate analyses were performed using the R statistical language ( $R$ 2. 13.1; R Development Core Team 2010) and ordination figures were made using Canoco Software (ter Braak and Šmilauer 1998). To remove large differences in scale among the original variables, input for redundancy analysis (RDA) consisted of $\log (\mathrm{x}+1)$ species abundance data using the "decostand" function in the "vegan" package. In an exploratory constrained ordination, the species composition of study sites was analyzed using detrended correspondence analysis (DCA; Hill and Gauch 1980), using Canoco Software. Species turnover, measured as standard deviation in the species response compared with the gradient length, was under three units $(\mathrm{SD}=2.93)$ and subsequent linear type ordination was implemented using RDA.

To explore the spatial structure of the assemblage, geographical position (geometrical means) of sites $(n=74)$ were entered into a principal coordinates of neighbor matrices (PCNM). This method can quantify spatial trends across a range of scales and is based on eigenvalue decomposition of a truncated matrix of geographic distance among sampling sites (Borcard and Legendre 2002). We used geographical coordinates of sample sites projected on a two-dimensional surface to compute the matrix of Euclidean distance. This matrix was then analyzed using the 'quick exploratory PCNM analysis' function in R software (available at www.bio.umon
treal.ca/numecolR/). The eigenvectors associated with positive eigenvalues were submitted to a forward selection test using the "forward.sel" function of the "packfor" package (Blanchet et al. 2008) with 999 permutations, retaining significant PCNM. The forward selection test used was based on a procedure that corrects for the inflated Type 1 error and overestimation of explained variance associated with classical forward selection (Blanchet et al. 2008).

Significant climate and habitat variables were selected using the "forward.sel" function with 999 permutations. All significant PCNM and environmental variables were used in a RDA using the "vegan" package. Finally, we used variance partitioning (with the "varpart" function in "vegan") to partition the variance explained by climate, habitat, and spatial variables. In the first level of decomposition, the spatial variables were partialled out of the analysis to determine the relative effect of space (significant PCNM axis) versus environment on the variance in the species data. In the second level of decomposition, the environmental variables were partitioned into two subsets of variables (climate and habitat), and each of the two subsets was sequentially partialled out of the analysis after considering the effects of the spatial variables. Permutation tests with 999 permutations were performed to assess the significance of constraints. To interpret the species response to climate variables, we produced a biplot including climate data as explanatory variables and habitat and space data as covariables.

\section{Statistical analysis: guild and species richness}

We classified bird species of the boreal forest into four different guild types: migratory strategy, spring arrival, feeding guilds, and distribution pattern (Appendix 1). The migratory strategy guild is divided into three groups: residents, short-distance, and long-distance migrants. The spring arrival 
Table 2. Summary of results of first and second level partial-RDA conducted to partition the percent variance in the distribution of birds explained by environmental variables and spatial variables (first level), and climate and habitat (second level).

\begin{tabular}{|c|c|c|c|}
\hline Description of analysis & Eigenvalues $^{\dagger}$ & $\%$ Variance explained ${ }^{+}$ & P Value $e^{\S}$ \\
\hline \multicolumn{4}{|l|}{ First level decomposition } \\
\hline Environmental variables explanatory; no covariables & 0.425 & $30 \%$ & 0.0009 \\
\hline Environmental variables explanatory; space covariables & 0.275 & $23 \%$ & 0.0009 \\
\hline Space variables explanatory; environmental covariables & 0.108 & $6 \%$ & 0.0009 \\
\hline \multicolumn{4}{|l|}{ Second level decomposition } \\
\hline Climate variables explanatory; space covariables & 0.215 & $19 \%$ & 0.0009 \\
\hline Habitat variables explanatory; space covariables & 0.104 & $8 \%$ & 0.0009 \\
\hline Climate variables explanatory; habitat and space covariables & 0.170 & $15 \%$ & 0.0009 \\
\hline Habitat variables explanatory; climate and space covariables & 0.059 & $4 \%$ & 0.0009 \\
\hline
\end{tabular}

${ }^{\dagger}$ Eigenvalue for each step quantifies the level of variation in the bird community explained by that step (total variation =

1.00).

*The $\%$ of variance explained refers to the adjusted $\mathrm{R}^{2}$.

${ }^{\S}$ The significance of each step is tested using a permutation test (999 permutations).

guild included two groups and excluded resident bird species: early spring arrival and late spring arrival. Early migrants are defined as species with a median spring arrival date in the study region before 8 May. The diet guild divided the bird species according to breeding season dietary preferences: mainly invertebrates (particularly insects), mix diet of insects and vegetation, and mainly seeds and berries. Distribution range included two groups: species whose northern breeding season distribution range extends well beyond the northern limit of our study region and species whose northern limit of their breeding season distribution corresponded to the northern limit of our study region or a little below. Guild classifications were derived from the literature (e.g., Gauthier and Aubry 1996, DesGranges and Morneau 2010). Statistical relationships between the axes derived from RDA and bird species richness, migratory strategy and spring arrival were analyzed through partial correlation analysis. The latter analysis was used to solve the problem of the interactions among both axes (Zar 1996). To determine whether diet groups differed in the proportion of early and late spring arrival groups within the long-distance migrants, we used a chi-square $\left(X^{2}\right)$ analysis of a contingency table with $\alpha=0.05$ (Zar 1996). Shortdistance migrants were excluded from this analysis because of their relatively low number in comparison to long distance migrants (6 short-distance migrants vs. 28 long-distance migrants).

\section{RESULTS}

\section{Bird community response}

A total of 79 bird species were detected among the 74 sites. To determine the response of forest birds to climate and habitat variables, only species detected at more than $5 \%$ of our 337 stations were included in the statistical analyses. The Whitewinged Crossbill (Loxia leucoptera) was excluded from the analyses. This species is considered an irruptive conifer seedeating species and its breeding cycle is closely tied to cone availability (Benkman 1992). A highly productive year can thus dramatically increase their abundance which can lead to invasions, as was the case for 2008 in our study area. Thus, 44 species were used in our statistical analyses (Appendix 1).

There was a significant relationship between space and community composition. Using a forward selection procedure, six PCNM variables were selected out of a total of 32. The same technique yielded four significant climate variables and three significant habitat variables. Significant climate variables included the number of growing degree days (GDD; $\mathrm{F}=9.902, \mathrm{p}=0.001$, adjusted $\mathrm{R}^{2}=0.109$ ), breeding season precipitation (BSP; $\mathrm{F}=6.767, \mathrm{p}=0.001$, adjusted $\mathrm{R}^{2}$ $=0.066$ ), start of the growing season (SGS; $F=2.808, p=$ 0.001 , adjusted $\mathrm{R}^{2}=0.020$ ), and breeding season temperature (BST; $F=2.566, p=0.001$, adjusted $\left.R^{2}=0.018\right)$. Significant habitat variables included the percentage of black spruce (BS; $\mathrm{F}=2.214, \mathrm{p}=0.004$, adjusted $\mathrm{R}^{2}=0.013$ ), the percentage of balsam fir (BF; $F=1.904, p=0.047$, adjusted $R^{2}=0.011$, and the percentage of white spruce $(\mathrm{WS} ; \mathrm{F}=1.614, \mathrm{p}=0.047$, adjusted $\mathrm{R}^{2}=0.007$ ).

There was a highly significant relationship between the set of climate, habitat, and spatial variables and community composition (Table 2). Climate, habitat, and spatial variables explained $30 \%$ (adjusted $\mathrm{R}^{2}$ ) of the variation in composition. Figure 2A depicts the percentage of this variation explained by the first level of decomposition, which quantified the variance explained by environmental variables independent of spatial variables. Environmental variables with confounding spatial variables removed accounted for $23 \%$ (adjusted $\mathrm{R}^{2}$ ) of the variation in bird community structure. In contrast, spatial variables with confounding environmental 
variables removed explained $6 \%$ of the variation in bird community structure. Climate, habitat, and spatial variables alone explained $15 \%, 4 \%$, and $6 \%$ of the total variation in composition, respectively (Fig. 2B).

The first axis of the redundancy analysis ordination diagram explained $11 \%$ of the variance in bird composition. This axis represented a gradient from high breeding season temperature and high number of degree days of growing season to colder summer conditions in the study area (Fig. 3). The second axis explained $4 \%$ of the variance in the species data, and mainly represented a precipitation gradient. It is noteworthy to mention that most of the species closely associated with high breeding season temperature were at the northern limit of their

Fig. 2. A. Percent of total variance in the bird abundance data explained by environmental variables and spatial variables. B. Percent of total variance in the bird abundance data due to environmental factors explained by climate and habitats variables, as well as variance explained by each combination of factors. Values $<0$ are not shown.

A.

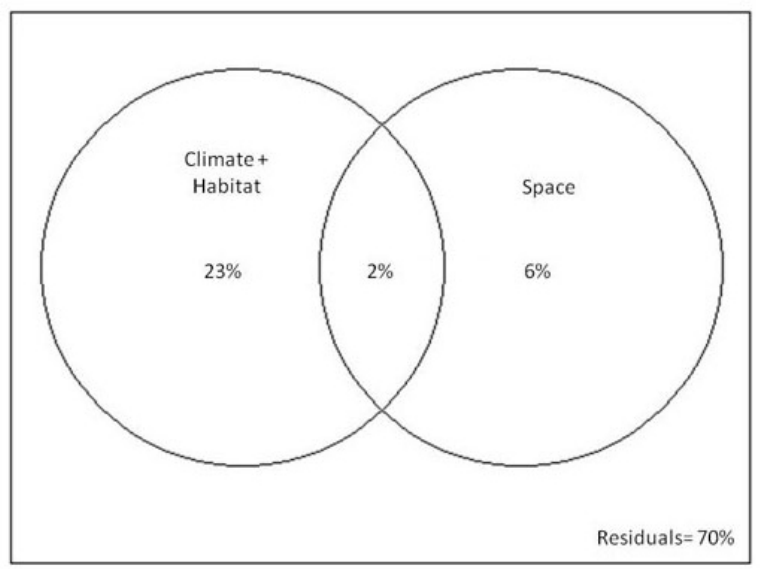

B.

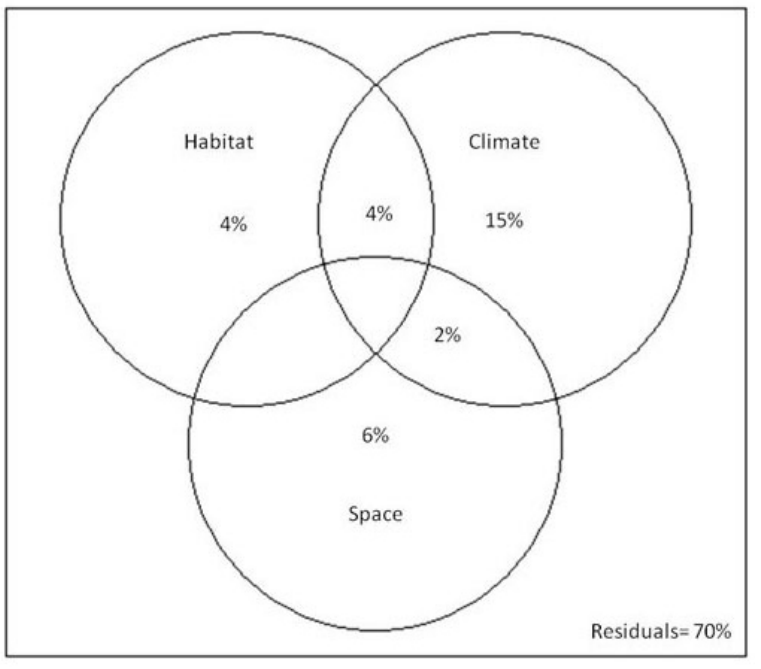

breeding season distribution whereas species found at the other end of the temperature gradient are those whose northern breeding season distribution range extends well beyond the northern limit of our study region.

The Magnolia Warbler (MAGW; Setophaga magnolia), the Red-breasted Nuthatch (RBNU; Sitta canadensis), and the Nashville Warbler (NAWA; Oreothlypis ruficapilla) were strongly associated with stands having the warmest summer temperature whereas the Fox Sparrow (FOSP; Passerella iliaca), the Dark-eyed Junco (DEJU; Junco hyemalis), and the Common Redpoll (CORE; Carduelis flammea) were mostly encountered in stands with low summer temperature and high summer precipitation. The Tennessee Warbler (TEWA; Oreothlypis peregrina), the Boreal Chickadee (BOCH; Poecile hudsonia), and the Pine Siskin (PISI; Spinus pinus) were closely associated with stands having relatively high summer temperature and high summer precipitation. The Ruby-crowned Kinglet (RCKI; Regulus calendula) and the Orange-crowned Warbler (OCWA; Oreothlypis celata) were mostly found in dryer forest stands.

\section{Species richness and guilds}

Based on partial correlation analysis, bird species richness seems to be influenced mainly by temperature after controlling for the precipitation gradient (Table 3). This analysis also revealed a positive correlation between all guild types and temperature. The resident species seems to be influenced by both the temperature and precipitation gradient (Table 3). The contingency analysis revealed that spring arrival phenology and food diet are not independent $\left(X^{2}=6.711\right.$, d.f. $=1, \mathrm{p}=$ $0.009)$. The number of bird species that feed mainly on insects during the breeding season was significantly higher among the late spring arrival group.

\section{DISCUSSION}

The objective of the study was to determine to what extent climate can explain the structure and diversity of forest bird communities by sampling bird abundance in homogenous mature spruce stands. By analyzing two environmental factors, climate and habitat, and systematically isolating the effects of each on bird community structure and composition, we revealed details about species-climate relationships that would otherwise remain undetected. For bird communities inhabiting mature black spruce stands in the boreal forest of the Québec-Labrador peninsula, climate variables appear to be most important in explaining species distribution and abundance because nearly $15 \%$ in the variation in the distribution of the 44 bird species studied can be explained by climate. The vegetation variables were responsible for a much smaller amount of the explained variation (4\%). The smaller amount of explained variation accounted for by the habitat dataset might be attributed to the similarity of vegetation composition between similarly aged stands. Snag availability, which is an important habitat attribute for woodpeckers 
Table 3. Partial correlation analysis (d.f. $=74)$ between bird species richness, migratory strategy, and spring arrival phenology and first and second axes derived from Redundancy Analysis (RDA).

\begin{tabular}{|c|c|c|c|}
\hline & & First RDA axis ${ }^{\dagger}$ & Second RDA axis ${ }^{\ddagger}$ \\
\hline & & Temperature gradient & Precipitation gradient \\
\hline Bird species richness & & $0.41 t=3.89 * * *$ & $0.03 t=0.27 \mathrm{NS}$ \\
\hline \multicolumn{4}{|l|}{ Migration strategy } \\
\hline & Long distance migrants & $0.24 t=2.09^{*}$ & $0.15 t=1.29 \mathrm{NS}$ \\
\hline & Short distance migrants & $0.71 t=8.61 * * *$ & $0.20 t=1.81 \mathrm{NS}$ \\
\hline & Residents & $0.36 t=3.21 * *$ & $-0.32 t=-2.85^{*}$ \\
\hline \multicolumn{4}{|l|}{ Spring arrival } \\
\hline & Early spring arrival & $0.34 t=3.11 * *$ & $0.13 t=1.17 \mathrm{NS}$ \\
\hline & Late spring arrival & $0.40 t=3.75 * * *$ & $0.18 t=1.58 \mathrm{NS}$ \\
\hline
\end{tabular}

$\uparrow$ The effects of precipitation were controlled

$*$ The effects of temperature were controlled Not significant $* \mathrm{p}>0.05, * * \mathrm{p}<0.05, * * * \mathrm{p}<0.001$

Fig. 3. Ordination based on redundancy analysis (RDA) with spatial and habitat variables as covariates showing the first and second axes. Species are indicated by four-letter codes (see Appendix 1 for species codes). Arrows represent significant climate variables (GDD: number of growing days, BST: breeding season temperature, BSP: breeding season precipitation, SGS: start of growing season). The proximity between bird species and arrows indicates the importance of the influence of that environmental variable on the abundance and distribution of the bird species. Axis 1 runs horizontally, axis 2 runs vertically.

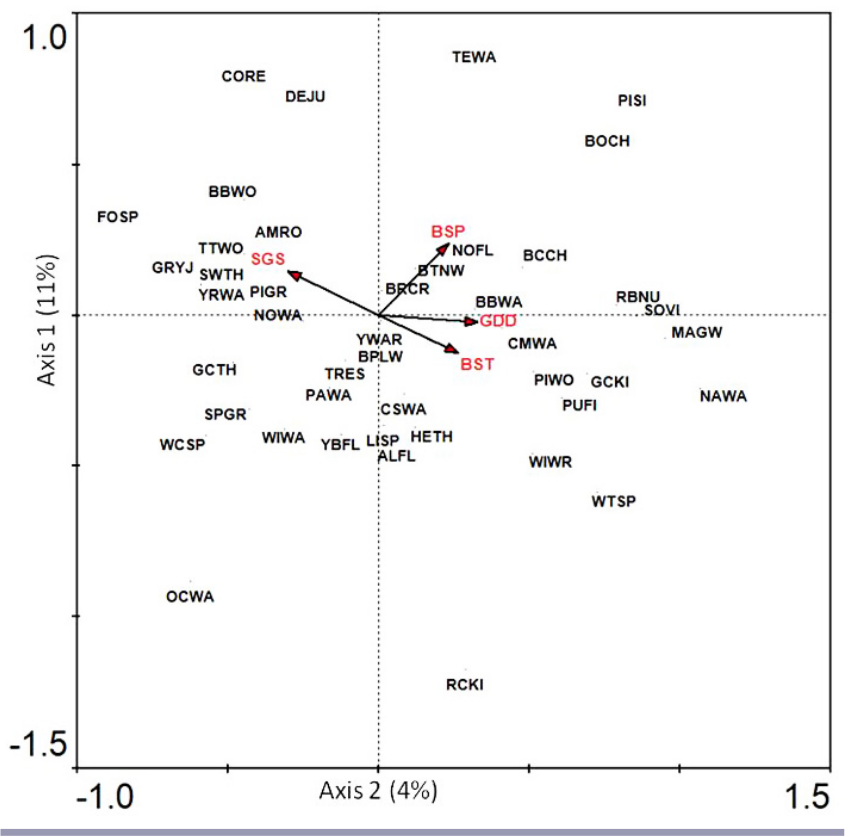

(Drapeau et al. 2009), was not measured. Had we included the latter variable, the habitat dataset might have explained more variance in the distribution of forest birds.

The results of this study suggest that climate plays an important role in shaping biogeographical patterns of composition and avian diversity in the boreal forest of Québec. These results are consistent with the findings of Johnson (1994) and Currie (2001) who found that the contemporary patterns of bird distribution in the conterminous United States covary strongly with summer temperature and moisture and with those of DesGranges and Morneau (2010) who found climate to play an important role in bird distribution in southern Québec. The eastern boreal region of Québec and Labrador is characterized by a subhumid climate that influences stand structure and composition because increased precipitation creates a longer fire return cycle (Boucher et al. 2003). Our results show, however, that late spring/early summer temperature seems to be more important than precipitation in driving variation in bird species diversity at the scale of our analysis during the breeding season. Honkanen et al. (2010) argue that solar energy, rather than habitat heterogeneity is the main driver of species richness in boreal forest birds. The latter study found that bird species richness of long-distance migrants was positively correlated with the number of growing degree days.

In northern Québec, bird species association with climate differs with that found in the southern region of Québec (DesGranges and Morneau 2010). Certain species associated with a wet and cool climate in the latter study, such as the Baybreasted Warbler and Tennessee Warbler, were associated with the warmer climate in our more northern study. Both species were, however, found to be at the northern limit of their summer distribution range, which could explain their associations with warmer conditions during the breeding season in the northern ecosystems. Although both species' 
populations are known to fluctuate widely depending on spruce budworm (Choristoneura fumiferana) outbreaks in eastern North America (Cooper et al. 1997, Rimmer et al. 1998), significant recent short-term declines have been recorded, mainly for the Bay-breasted Warbler (Hill and Hagan 1991). It is not known whether the cause of this decline is related to recent temperature increases. However, if birds such as the Bay-breasted Warbler are breeding near the geographical limit of their food resources, small declines in the favorable climate conditions could result in relatively large decreases in reproduction or survival (Martin 1987). Species that were mostly found in colder regions such as Common Redpoll, Dark-eyed Junco, Fox Sparrow, American Robin (Turdus migratorius), Three-toed Woodpecker (Picoides dorsalis), and Gray Jay (Perisoreus canadensis) were species for which the northern summer distribution range extends well beyond the northern limits of our study region. This comparison shows that the northern and southern range boundaries of species are not equally sensitive to the temperature gradient across the region, as was the case in Honkanen et al.'s (2010) study in Finland.

The relationship between local climate conditions and the distribution of forest birds is further supported by our results that suggest that the number of long-distance migrants, shortdistance migrants, and residents are significantly influenced by spring temperature. All short-distance migrants in our bird community arrive early in the spring. Because of the close proximity with their breeding sites, climatic cues could possibly have an impact on short-distance migrant distribution (Jenni and Kery 2003). To a lesser extent, the number of longdistance migrants was associated with spring temperature. Long-distance migrants seem to distribute themselves into two groups across the temperature gradient. Neotropical species that migrate early in the spring such as the Fox Sparrow, Swainson's Thrush, and Yellow-rumped Warbler (Setophaga coronata ) were mostly associated with colder sites, whereas neotropical species that migrate late in the spring such as Baybreasted Warbler, Cape May Warbler (Setophaga tigrina), and Magnolia Warbler were mostly found in warmer sites. Interestingly, among all neotropical late migrants, 13 species out of 16 feed mainly on insects during the breeding season whereas among the neotropical early migrants 9 out of 12 species have a mixed diet consisting of vegetation and insects. Among the neotropical species, late migrants in particular might be the most sensitive to climate change because their food requirements are associated with local climate conditions. Recent studies have highlighted that long-distance migrants that mainly feed on invertebrates are considered more vulnerable to population declines because of mistiming between their migration schedule and maximal food abundance (Jenni and Kery 2003, Marra et al. 2005, Both 2010).
Surface air temperatures have increased in southern Québec during the period between 1960 and 2005, with significant warming being evident in the western, southern, and central parts of the province (Yagouti et al. 2008). Without a major reduction in global greenhouse gas emissions, this warming should continue in the future, with estimated increases in average annual temperatures in Québec of $2^{\circ}-5^{\circ} \mathrm{C}$ from now until the end of the century (2090-2099; IPCC 2007). At this point in time, we cannot say whether climate change in the eastern boreal forest of Canada will be detrimental (Devictor et al. 2008, Rodenhouse et al. 2008, Virkkala et al. 2008) or mostly beneficial (D. Berteaux, N. Casajus, and Y. Gendreau, unpublished manuscript) to the boreal avifauna because the extent to which behavioral plasticity can enhance the benefits of favorable weather or lessen severe conditions is unknown. Because forest birds seem to respond differently to a broad scale climate gradient, field research and demographic modeling efforts should focus on understanding the effects of climate change on birds that are more susceptible to short-term climate change such as neotropical late migrants in the northern regions and link the changes in abundance and distribution of such species to the phenological response across trophic levels.

Responses to this article can be read online at: http://www.ace-eco.org/vol7/iss 1/art2/responses/

\section{Acknowledgments:}

The authors would like to thank Dr. Dan W. McKenney of the Canadian Forest Service, Sault Ste. Marie for giving us permission to use the Forest Canada climatological data bank and for making his employee Pia Papadopol available for computing and extracting climatological parameters for us. We also thank Martine Benoit, Pierre Cantin, Marilyn Labrecque, Valérie Plourde, and David Savoie (all from the Groupe d'intervention et de recherche en environnement, Québec) for technical assistance. Comments by two anonymous journal referees, and the associate editor Mikko Mönkkönen improved earlier versions of the manuscript. This project could not have been carried out without the technical and financial assistance of the Canadian Wildlife Service and the Wildlife Research Division of Environment Canada, Québec Region.

\section{LITERATURE CITED}

Benkman, C. W. 1992. White-winged Crossbill (Loxia leucoptera). In A. Poole, editor. The birds of North America online. Cornell Laboratory of Ornithology, Ithaca, New York, USA. [online] URL: http://bna.birds.cornell.edu/bna/species/027 
Berteaux, D., S. de Blois, J.-F. Angers, J. Bonin, N. Casajus, M. Darveau, F. Fournier, M. M. Humphries, B. McGill, J. Larivée, T.Logan, P. Nantel, C. Périé, F. Poisson, D. Rodrigue, S. Rouleau, R. Siron, W. Thuiller, and L. Vescovi. 2010. The CC-Bio Project: studying the effects of climate change on Quebec biodiversity. Diversity 2:1181-1204. http://dx.doi.org /10.3390/d2111181

Blanchet, F. G., P. Legendre, and D. Borcard. 2008. Forward selection of explanatory variables. Ecology 89:2623-2632. http://dx.doi.org/10.1890/07-0986.1

Borcard, D., and P. Legendre. 2002. All-scale spatial analysis of ecological data by means of principal coordinates of neighbour matrices. Ecological Modelling 153:51-68. http://d x.doi.org/10.1016/S0304-3800(01)00501-4

Both, C. 2010. Food availability, mistiming, and climatic change. Pages 129-148 in A. P. Møller, W. Fiedler, and P. Berthold, editors. Effects of climate change on birds. Oxford University Press, Oxford, UK.

Boucher, D., L. De Grandpré, and S. Gauthier. 2003. Développement d'un outil de classification de la structure des peuplements et comparaison de deux territoires de la pessière à mousses du Quebec. Forestry Chronicles 79:318-328.

Cooper, J. M., K. A. Enns, and M. G. Shepard. 1997. Status of the Bay-breasted Warbler in British Columbia. Wildlife Working Report No. WR-79, B. C. Ministry of Environment, Lands and Parks, Victoria, British Columbia, Canada.

Currie, D. J. 2001. Projected effects of climate change on patterns of vertebrate and tree species richness in the conterminous United States. Ecosystems 4:216-225. http://dx. doi.org/10.1007/s10021-001-0005-4

DesGranges, J.-L., and F. Morneau. 2010. Potential sensitivity of Quebec's breeding birds to climate change. Avian Conservation and Ecology 5(2): 5. [online] URL: http://www. ace-eco.org/vol5/iss2/art5/

Devictor, V., R. Julliard, D. Couvet, and F. Jiguet. 2008. Birds are tracking climate warming, but not fast enough. Proceedings of the Royal Society B 275:2743-2748. http://dx. doi.org/10.1098/rspb.2008.0878

Drapeau, P., A. Leduc, Y. Bergeron, S. Gauthier, and J.-P. L. Savard. 2003. Bird communities of old spruce-moss forests in the Clay Belt region: problems and solutions in forest management. Forestry Chronicle 79:531-540.

Drapeau, P., A. Nappi, L. Imbeau, and M. Saint-Germain. 2009. Standing deadwood for keystone bird species in the eastern boreal forest: managing for snag dynamics. Forestry Chronicle 85:227-234.

Gauthier, J., and Y. Aubry, editors. 1996. The breeding birds of Québec: atlas of the breeding birds of southern Québec. Association québécoise des groupes d'ornithologues,
Province of Québec Society for the Protection of Birds, Canadian Wildlife Service, Environment Canada, Québec Region, Montreal, Québec, Canada.

Hill, M. O., and H. G. Gauch. 1980. Detrended correspondence analysis: an improved ordination technique. Plant Ecology 42:47-58. http://dx.doi.org/10.1007/BF00048870

Hill, N. P., and J. M. Hagan, III. 1991. Population trends of some northeastern North American landbirds: a half-century of data. Wilson Bulletin 103:165-182.

Honkanen, M., J.-M. Roberge, A. Rajasärkkä, and M. Mönkkönen. 2010. Disentangling the effects of area, energy and habitat heterogeneity on boreal forest bird species richness in protected areas. Global Ecology and Biogeography 19:61-71. http://dx.doi.org/10.1111/j.1466-8238.2009.00491. $\underline{x}$

Intergovernmental Panel on Climate Change (IPCC). 2007. Climate change 2007: the physical science basis. Contribution of Working Group I to the Fourth Assessment Report of the Intergovernmental Panel on Climate Change. S. Solomon, D. Qin, M. Manning, Z. Chen, M. Marquis, K. B. Averyt, M. Tignor and H. L. Miller, editors. Cambridge University Press, Cambridge, UK.

Jenni, L., and M. Kéry. 2003. Timing of autumn bird migration under climatic change: advances in long-distance migrants, delays in short-distance migrants. Proceedings of the Royal Society B 270:1467-1471. http://dx.doi.org/10.1098/rspb.200 $\underline{3.2394}$

Johnson, N. K. 1994. Pioneering and natural expansion of breeding distributions in western North American birds. Studies in Avian Biology 15:27-44.

Lemoine, N., and K. Böhning-Gaese. 2003. Potential impacts of global change on species richness of long distance migrants. Conservation Biology 17:577-586. http://dx.doi.org/10.1046/ j.1523-1739.2003.01389.x

Litynski, J. 1984. Classification numérique des climats mondiaux. PCM/WCP-63, Programme climatologique mondial. Organisation météorologique mondiale, Genève, Suisse.

Marra, P. P., C. M. Francis, R. S. Mulvihill, and F. R. Moore. 2005 The influence of climate on the timing and rate of spring bird migration. Oecologia 142:307-315. http://dx.doi.org/10. 1007/s00442-004-1725-x

Martin, T. E. 1987. Food as a limit on breeding birds: a lifehistory perspective. Annual Review of Ecology and Systematics 18:453-48. http://dx.doi.org/10.1146/annurev.es. $\underline{18.110187 .002321}$

McKenney, D. W., J. H. Pedlar, P. Papadopol, and M. F. Hutchinson. 2007. The development of 1901-2000 historical monthly climate models for Canada and the United States. 
Agricultural and Forest Meteorology 138:69-81. http://dx.doi. org/10.1016/j.agrformet.2006.03.012

Mengel, R. M. 1964. The probable history of species formation in some northern wood warblers (Parulidae). Living Bird 3/4:9-43.

Møller, A. P., W. Fiedler, and P. Berthold, editors. 2010. Effects of climate change on birds. Oxford University Press, Oxford, UK.

Moyes, K., D. H. Nussey, M. N. Clements, F. E. Guinness, A. Morris, S. Morris, J. M. Pemberton, L. E. B. Kruuk, and T. H. Clutton-Brock. 2011. Advancing breeding phenology in response to environmental change in a wild red deer population. Global Change Biology 17:2455-2469. http://dx.d oi.org/10.1111/j.1365-2486.2010.02382.x

Newton, I. 2003. The speciation and biogeography of birds. Academic, London, UK.

Norton, M. R., and S. J. Hannon. 1997. Songbird response to partial-cut logging in the boreal mixedwood forest of Alberta. Canadian Journal of Forest Research 27:44-53. http://dx.doi. org/10.1139/x96-149

R Development Core Team. 2010. R: A language and environment for statistical computing. $\mathrm{R}$ Foundation for Statistical Computing, Vienna, Austria.

Rimmer, C. C., and K. P. McFarland. 1998. Tennessee Warbler (Vermivora peregrina). In A. Poole and F. Gill, editors. The birds of North America, No. 350. The Birds of North America, Philadelphia, Pennsylvania, USA.

Robitaille, A., and J.-P. Saucier. 1998. Paysages régionaux du Québec méridional. Ministère des Resources naturelle, Gouvernement du Québec. Les publications du Québec, Québec, Canada.

Rodenhouse, N. L., S. N. Matthews, K. P. McFarland, J. D. Lambert, L. R. Iverson, A. Prasad, T. S. Sillett,and R. T. Holmes. 2008. Potential effects of climate change on birds of the Northeast. Mitigation and Adaptation Strategies for Global Change 13:517-540. http://dx.doi.org/10.1007/s11027 $\underline{-007-9126-1}$

Root, T. L. 1988. Environmental factors associated with avian distributional boundaries. Journal of Biogeography 15:489-505. http://dx.doi.org/10.2307/2845278

Root, T. L., J. T. Price, K. R. Hall, S. H. Schneider, C. Rosenzweig, and J. A. Pounds. 2003. Fingerprints of global warming on wild animals and plants. Nature 421:57-60. http: //dx.doi.org/10.1038/nature01333

Schmiegelow, F. K. A., and M. Mönkkönen. 2002. Habitat loss and fragment in dynamix landscapes: avian perspective from the boreal forest. Ecological Applications 12:375-389.
Tellería, J. L., and T. Santos. 1994. Factors involved in the distribution of forest birds in the Iberian Peninsula. Bird Study 41:161-169. http://dx.doi.org/10.1080/00063659409477216

Tellería, J. L., T. Santos, A. Sánchez, and A. Galarza. 1992. Habitat structure predicts bird diversity distribution in Iberian forests better than climate. Bird Study 39:63-68. http://dx.doi. org/10.1080/00063659209477100

ter Braak, C. J. F., and P. Šmilauer. 1998. CANOCO Reference Manual and user's Guide to Canoco for windows. Software for Canonical Community Ordination (Version 4). Microcomputer Power, Ithaca, New York, USA.

Thomas, C. D., and J. J. Lennon. 1999. Birds extend their ranges northwards. Nature 399:213. http://dx.doi.org/10.1038 $\underline{120335}$

Virkkala, R., R. K. Heikkinen, N. Leikola, and M. Luoto. 2008. Projected large-scale range reductions of northern-boreal land bird species due to climate change. Biological Conservation 141:1343-1353. http://dx.doi.org/10.1016/j.biocon.2008.03.007

Virkkala, R., and A. Rajasärkkä. 2011. Climate change affects populations of northern birds in boreal protected areas. Biology Letters 7:395-398. http://dx.doi.org/10.1098/rsbl.201 $\underline{0.1052}$

Walther, G.-R., E. Post, P. Convey, A. Menzel, C. Parmesan, T. J. C. Beebee, J.-M. Fromentin, O. Hoegh-Guldberg, and F. Bairlein. 2002. Ecological responses to recent climate change. Nature 416:389-395. http://dx.doi.org/10.1038/416389a

Wormworth, J., and C. Sekercioglu. 2011. Winged sentinels: birds and climate change. Cambridge University Press, New York, New York, USA. http://dx.doi.org/10.1017/CBO97811 $\underline{39150026}$

Yagouti, A., G. Boulet, L. Vincent, L. Vescovi, and É. Mekis. 2008. Observed changes in daily temperature and precipitation indices for southern Quebec, 1960-2005. Atmosphere-Ocean 46:243-256. http://dx.doi.org/10.3137/ao.460204

Zar, J. H. 1996. Biostatistical analysis. Third Edition. Prentice Hall, Upper Saddle River, New Jersey, USA. 
Appendix 1. Names, abbreviated codes, frequency of occurrence (Occ.), migratory strategy (M.S.; LD; long-distance migrant, SD; short-distance migrant, R; resident), spring arrival phenology (S.A.; early; early spring arrival, late; late spring arrival), diet guild (D.G.; mix; mix diet of insects and vegetation) and distribution range (EN; species whose northern breeding season distribution range extends well beyond the northern limit of our study region, NL, species whose northern limit of their breeding season distribution corresponded to the northern limit of our study region or little below) of 44 forest bird species detected in mature conifer forest stands sampled in the summers of 2007 to 2009 ( $n=74)$, Québec. Species are listed from most abundant to least abundant.

\begin{tabular}{|c|c|c|c|c|c|c|c|}
\hline English Name & Scientific Name & CODE & Occ. & M.S. & S.A & D.G. & D.R. \\
\hline Ruby-crowned Kinglet & Regulus calendula & RCKI & 95.94 & LD & early & insects & EN \\
\hline White-throated Sparrow & Zonotrichia albicollis & WTSP & 95.94 & LD & early & $\operatorname{mix}$ & NL \\
\hline Dark-eyed Junco & Junco hyemalis & DEJU & 91.89 & $\mathrm{SD}$ & early & $\operatorname{mix}$ & EN \\
\hline Yellow-rumped Warbler & Setophaga coronata & YRWA & 89.18 & LD & early & insects & EN \\
\hline Swainson's Thrush & Catharus ustulatus & SWTH & 87.83 & LD & early & $\operatorname{mix}$ & NL \\
\hline Gray Jay & Perisoreus canadensis & GRYJ & 81.08 & $\mathrm{R}$ & na & $\operatorname{mix}$ & $\mathrm{EN}$ \\
\hline Tennessee Warbler & Oreothlypis peregrina & TEWA & 72.97 & LD & late & insects & NL \\
\hline Hermit Thrush & Catharus guttatus & HETH & 70.27 & LD & early & $\operatorname{mix}$ & NL \\
\hline Fox Sparrow & Passerella iliaca & FOSP & 68.91 & $\mathrm{LD}$ & early & $\operatorname{mix}$ & EN \\
\hline American Robin & Turdus migratorius & AMRO & 63.51 & LD & early & $\operatorname{mix}$ & $\mathrm{EN}$ \\
\hline Boreal Chickadee & Poecile hudsonicus & $\mathrm{BOCH}$ & 58.1 & $\mathrm{R}$ & na & $\operatorname{mix}$ & $\mathrm{EN}$ \\
\hline Yellow-bellied Flycatcher & Empidonax flaviventris & YBFL & 54.05 & LD & late & $\operatorname{mix}$ & NL \\
\hline Spruce Grouse & Falcipennis canadensis & SPGR & 44.59 & $\mathrm{R}$ & na & seeds/berries & EN \\
\hline Blackpoll Warbler & Setophaga striata & BPLW & 43.24 & $\mathrm{LD}$ & late & insects & EN \\
\hline Magnolia Warbler & Setophaga magnolia & MAGW & 41.89 & $\mathrm{LD}$ & late & insects & NL \\
\hline Northern Waterthrush & Parkesia noveboracensis & NOWA & 41.89 & LD & late & insects & EN \\
\hline Winter Wren & Troglodytes hiemalis & WIWR & 40.54 & $\mathrm{SD}$ & early & insects & NL \\
\hline Lincoln's Sparrow & Melospiza lincolnii & LISP & 39.18 & LD & early & $\operatorname{mix}$ & EN \\
\hline Pine Siskin & Spinus pinus & PISI & 37.83 & $\mathrm{R}$ & na & seeds/berries & NL \\
\hline Golden-crowned Kinglet & Regulus satrapa & GCKI & 33.78 & SD & early & $\operatorname{mix}$ & NL \\
\hline Nashville Warbler & Oreothlypis ruficapilla & NAWA & 33.78 & LD & late & insects & NL \\
\hline Pine Grosbeak & Pinicola enucleator & PIGR & 32.43 & $\mathrm{R}$ & na & $\operatorname{mix}$ & EN \\
\hline Common Redpoll & Acanthis flammea & CORE & 27.02 & $\mathrm{R}$ & na & seeds/berries & EN \\
\hline Alder Flycatcher & Empidonaux alnorum & ALFL & 25.67 & LD & late & insects & NL \\
\hline Red-breasted Nuthatch & Sitta canadensis & RBNU & 24.32 & $\mathrm{SD}$ & early & insects & NL \\
\hline Orange-crowned Warbler & Oreothlypis celata & OCWA & 24.32 & LD & late & $\operatorname{mix}$ & NL \\
\hline White-crowned Sparrow & Zonotrichialeucophrys & WCSP & 22.97 & LD & early & $\operatorname{mix}$ & $\mathrm{EN}$ \\
\hline Wilson's Warbler & Cardellina pusilla & WIWA & 21.62 & LD & late & insects & EN \\
\hline Yellow Warbler & Setophaga petechia & YWAR & 21.62 & LD & late & $\operatorname{mix}$ & NL \\
\hline Three-toed Woodpecker & Picoides dorsalis & TTWO & 20.27 & $\mathrm{R}$ & na & insects & EN \\
\hline Gray-cheeked Thrush & Catharus minimus & GCTH & 13.51 & LD & late & insects & EN \\
\hline Solitary Vireo & Vireo solitarius & SOVI & 13.51 & LD & early & insects & NL \\
\hline Purple Finch & Carpodacus purpureus & PUFI & 12.16 & $\mathrm{SD}$ & early & seeds/berries & NL \\
\hline Black-backed Woodpecker & Picoides arcaticus & BBWO & 12.16 & $\mathrm{R}$ & na & insects & NL \\
\hline Pileated Woodpecker & Dryocopus pileatus & PIWO & 12.16 & $\mathrm{R}$ & na & $\operatorname{mix}$ & NL \\
\hline Cape May Warbler & Setophaga tigrina & CMWA & 10.81 & LD & late & insects & NL \\
\hline Bay-breasted Warbler & Setophaga castanea & BBWA & 10.81 & LD & late & insects & NL \\
\hline Black-throated Green Warbler & Setophaga virens & BTNW & 9.45 & LD & late & insects & NL \\
\hline Palm Warbler & Setophaga palmarum & PAWA & 9.45 & LD & late & insects & NL \\
\hline Chestnut-sided Warbler & Setophaga pensylvanica & CSWA & 9.45 & LD & late & insects & NL \\
\hline Black-capped Chickadee & Poecile atricapilla & $\mathrm{BCCH}$ & 8.1 & $\mathrm{R}$ & na & $\operatorname{mix}$ & NL \\
\hline Northern Flicker & Colaptes auratus & NOFL & 8.1 & LD & early & $\operatorname{mix}$ & NL \\
\hline Tree Swallow & Tachycineta bicolor & TRES & 6.75 & LD & early & $\operatorname{mix}$ & NL \\
\hline Brown Creeper & Certhia americana & BRCR & 6.75 & $\mathrm{SD}$ & early & $\operatorname{mix}$ & NL \\
\hline
\end{tabular}

*na; not applied for resident species 